\title{
Deployment of Radioactive Waste Disposal Facility with the Introduction of Nuclear Power Plants (NPP) in Kenya
}

\author{
A. Shadrack and C. L. Kim* \\ KEPCO International Nuclear Graduate School
}

\begin{abstract}
This paper describes basic plans for the development of a radioactive waste disposal facility with the introduction of Nuclear Power Plants (NPPs) for Kenya. The specific objective of this study was to estimate the total projected waste volumes of low- and intermediate-level radioactive waste (LILW) expected to be generated from the Kenyan nuclear power programme. The facility is expected to accommodate LILW to be generated from operation and decommissioning of nuclear power plants for a period of 50 years. An on-site storage capacity of $700 \mathrm{~m}^{3}$ at nuclear power plant sites and a final disposal repository facility of more than 7,000 $\mathrm{m}^{3}$ capacity were derived by considering Korean nuclear power programme radioactive waste generation data, including Kori, Hanbit, and APR 1400 nuclear reactor data. The repository program is best suited to be introduced roughly 10 years after reactor operation. This study is important as an initial implementation of a national LILW disposal program for Kenya and other newcomer countries interested in nuclear power technology.
\end{abstract}

Keywords: Nuclear power plants, Radioactive waste, Disposal facility, Newcomer country, Disposal capacity

\section{INTRODUCTION}

The deployment of a lasting solution disposal facility is a major concern for both present and future nuclear applications. When assessing radioactive waste disposal options, factors such as waste volume, waste classification, size of nuclear program, reactor lifetime, plan sustainability, timeline, compliancy with national policies, human resources, and public perception should be considered.

Disposal is the final stage in radioactive waste management, the purpose of which is to isolate wastes from the biosphere into respective repositories until radioactive decay renders them non-hazardous. Appropriate selection of a disposal option is important in terms of economics, efficiency, and safety [1].

When planning a disposal program, facilities need to be commissioned in time in order to provide the required

Received : July 31, 2013 - Revised : August 09, 2013 - Approved : August 19, 2013

*Corresponding Author : C. L. Kim

KEPCO International Nuclear Graduate School, Dept of Nuclear Power Plants Engineering Tel : +82.10.2440.4590 E-mail : clkim@kings.ac.kr

1446-1 Shinam-RI, Seosaeng-Myeon, Ulsan 689-882, Republic of Korea disposal capacity. The implementation plan should clearly define milestones for technical activities consistent with the anticipated waste generation.

The disposal options that have been suggested and prioritized for selection in this study included: on-site storage, international storage, direct disposal, deferred disposal, shared disposal, and near surface disposal.

Kenya plans to become the $2^{\text {nd }}$ African nuclear power generation country after South Africa. The country intends to run a nuclear power programme comprising 4 units of 1GWe each from 2022 through 2031.

The nuclear power program will inevitably generate wastes that are hazardous to human health and the environment, and therefore a reliable radioactive waste disposal facility is a necessity.

The purpose of this paper was to deploy a disposal option for LILW wastes with the introduction of nuclear power plants for Kenya. This study is important as an initial implementation of a national LILW disposal program for newcomer countries.

\subsection{Current \& Future Radioactive Waste}

In Kenya, radioactive waste is generated from the use of radioactive materials in medicine, industry, education and research, as depicted in fig. 1 and 2. 
C. L. Kim et al. : Deployment of Radioactive Waste Disposal Facility with the Introduction of Nuclear Power Plants (NPP) in Kenya

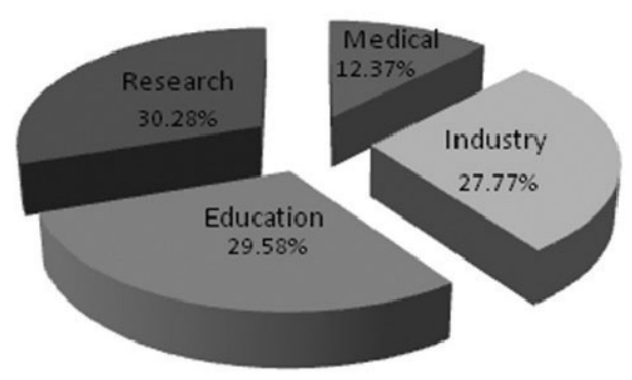

Fig. 1. Application of radioactive sources in Kenya.

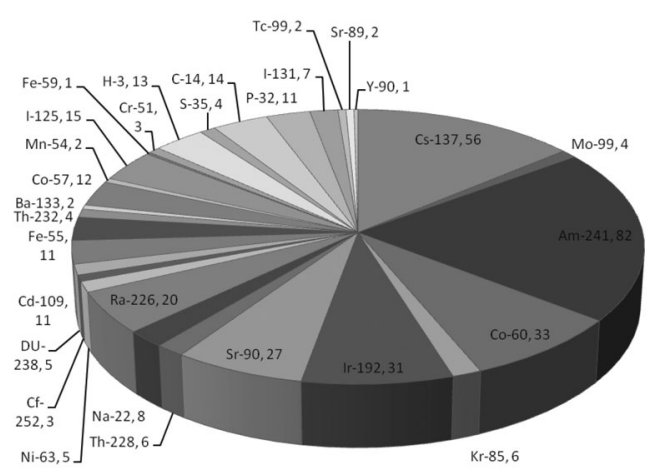

Fig. 2. Current radioactive sources/waste in Kenya.

Table 1-1. Current \& future radioactive waste in Kenya

\begin{tabular}{l|l}
\hline \multicolumn{1}{c|}{ Waste form } & \multicolumn{1}{c}{ Waste generated } \\
\hline Research reactors & EW,VLLW,LILW,HLW,SF,SSS \\
\hline Fuel production & VLLW-UW,LLW-UW \\
\hline Radioisotope facility & EW,VLLW,LILW,HLW,SSS \\
\hline Nuclear reactors & EW,VLLW,LILW,HLW,SF \\
\hline Oil exploration & NORM \\
\hline Research & EW,VLLW,LLW \\
\hline Medicine & EW,VLLW,LLW \\
\hline Industry & EW,VLLW,LILW,SSS \\
\hline Agriculture & EW,VLLW,LILW,SSS \\
\hline
\end{tabular}

Future radioactive waste is expected from nuclear reactors, oil exploration, radioisotope and fuel production, and research reactors. Table 1-1 depicts both current and future radioactive waste.

\subsection{Classification Of Radioactive Waste In Kenya}

Kenya follows the guidelines of the International Atomic Energy Agency (IAEA) regarding the definition
Table 1-2. Waste classification according to IAEA [2]

\begin{tabular}{|c|c|}
\hline \multicolumn{2}{|r|}{ Classification of radioactive waste based on IAEA } \\
\hline EW & $\begin{array}{l}\text { - Meets clearance, exemption, and exclusion level } \\
\cdot \text { Minimum dose limit of } 10 \mu \mathrm{Sv}\end{array}$ \\
\hline VSLW & $\begin{array}{l}\text { - Waste containing very short half-lives } \\
\cdot \text { Can be stored for decay for few years }\end{array}$ \\
\hline VLLW & $\begin{array}{l}\text { - Does not meet criteria for EW } \\
\cdot \text { Does not need isolation/containment } \\
\cdot \text { Suitable landfill disposal facility }\end{array}$ \\
\hline LLW & $\begin{array}{l}\text { - Above EW with limited } \\
\text { - Requires isolation \& containment } \\
\text { Thermal power below } 2 \mathrm{~kW} / \mathrm{m}^{3} \\
\text { - Suitable for near surface disposal }\end{array}$ \\
\hline ILW & $\begin{array}{l}\text { - Requires containment/isolation } \\
\text { Contain long-lived radionuclides } \\
\text { - Thermal power below } 2 \mathrm{~kW} / \mathrm{m}^{3} \\
\text { - Suitable for intermediate disposal }\end{array}$ \\
\hline HLW & $\begin{array}{l}\cdot \text { Waste that generates heat } \\
\cdot \text { Waste with long-lived radionuclides } \\
\cdot \text { Thermal power above } 2 \mathrm{~kW} / \mathrm{m}^{3} \\
\cdot \text { Suitable for deep geological disposal }\end{array}$ \\
\hline $\begin{array}{l}\text { ※W: } \\
\text { VLL } \\
\text { LLW } \\
\text { LILV } \\
\text { HLW } \\
\text { SF: S } \\
\text { VLL } \\
\text { LLW } \\
\text { NOR } \\
\text { SSS: } \\
\text { GT-1 } \\
\text { GT-K } \\
\text { Cogn } \\
\text { MSD } \\
\text { Nucl } \\
\text { Geot }\end{array}$ & $\begin{array}{l}\text { Very low level waste } \\
\text { ow level waste } \\
\text { Low - and intermediate level waste } \\
\text { High level waste } \\
\text { nt fuel } \\
\text { UW: Very low level uranium waste } \\
\text { W: Low level uranium waste } \\
\text { : Naturally occurring radioactive materials } \\
\text { ent sealed sources } \\
\text { : Gas turbine natural gas } \\
\text { RO: Gas turbine kerosene } \\
\text { logeneration } \\
\text { Medium speed diesel } \\
\text { luclear } \\
\text { eothermal }\end{array}$ \\
\hline
\end{tabular}

and classification of radioactive waste. Based on the IAEA guidelines, radioactive wastes currently in Kenya are classified according to their levels of radioactivity, half-life, and potential risk they pose for technical and safety purposes. But for the purposes of this study, LLW and ILW are combined together as LILW.

\section{KENYA'S NUCLEAR POWER PROGRAMME}

The Kenyan nuclear power program development agenda is anchored by the vision 2030 aimed at creating a globally competitive and prosperous country with a high quality of life and transforming Kenya into an industrialized, middle-income country through the provision of high quality life to its citizens.

The vision is anchored on three key pillars: economic, 


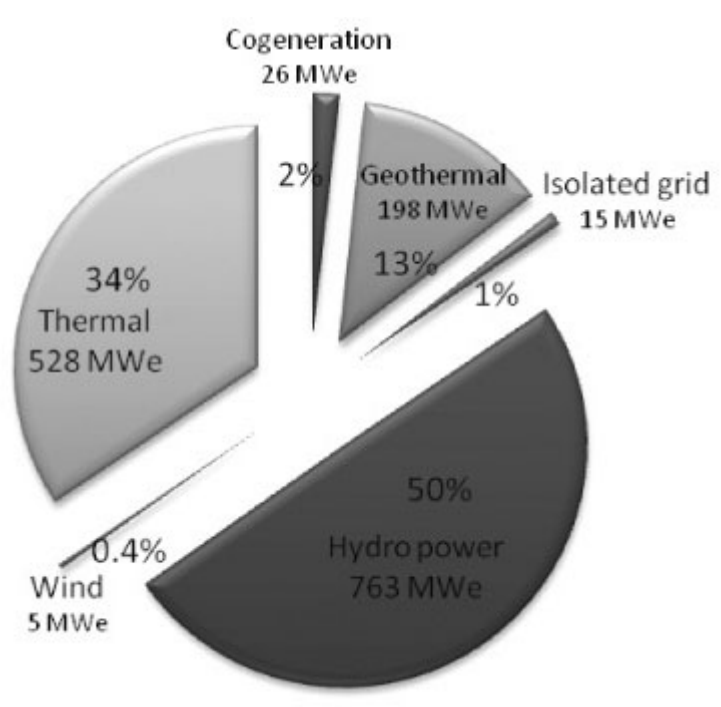

Fig. 3. Current energy mix in Kenya.

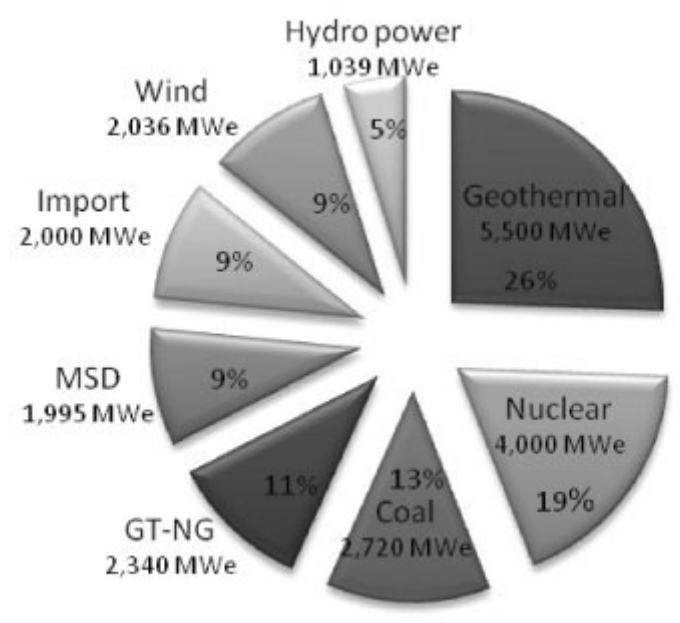

Fig. 4. Future energy mix in Kenya.

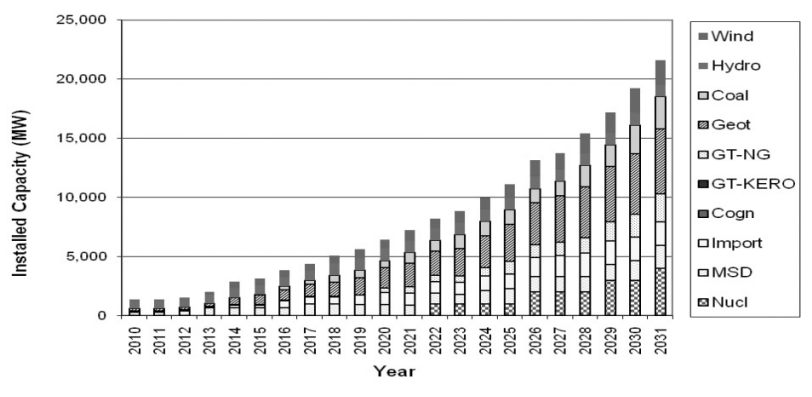

Fig. 5. Projected power generation mix [3]. social, and political bases. Energy is one of the infrastructural enablers upon which the economic, social, and political pillars of this development will be built.

The need for nuclear energy was initiated by the rising demand for power in the country due to accelerated investment in the economy. Kenya's energy demand has been on a consistent rise in recent years and it has become imperative to diversify the country's energy sources to meet this demand [3]. The pie charts below depict both the current and future energy mix for Kenya.

The Ministry of Energy proposed the use of nuclear energy for the purposes of electricity generation in the draft national energy policy. The least cost power development plan (LCPDP) also recognized the need for inclusion of nuclear energy in Kenya's energy mix. The LCPDP forecasts that the country's peak electricity demand will be over 16,905 MWe by the year 2031, requiring an installed capacity of 21,620 MWe for industrial, commercial, and domestic use.

According to the LCPDP, the first nuclear power plant of capacity 1,000 MWe is expected to be commissioned by 2022. The nuclear electricity project committee (NEPC) was established by the Kenya gazette Vol.CXIINo.123, Gazette Notice No. 14188 on the $19^{\text {th }}$ November 2010 , the mandate of which is to drive the nuclear energy roadmap for Kenya.

This committee was later transformed into the Kenya Nuclear Electricity Board (KNEB) in November 2012, as a statutory body through legal Notice No. 131 issued under the State Corporation Act, Cap 446 laws of Kenya [3].

Kenya has ratified 10 treaties including the NonProliferation Treaty (NPT), Comprehensive Safeguards Agreement (CSA), Convention on Physical Protection of Nuclear Materials (CPPNM), Additional Protocol under the Nuclear Non-proliferation Treaty (APNPT), and CPPNM Amendment to the Physical Protection of

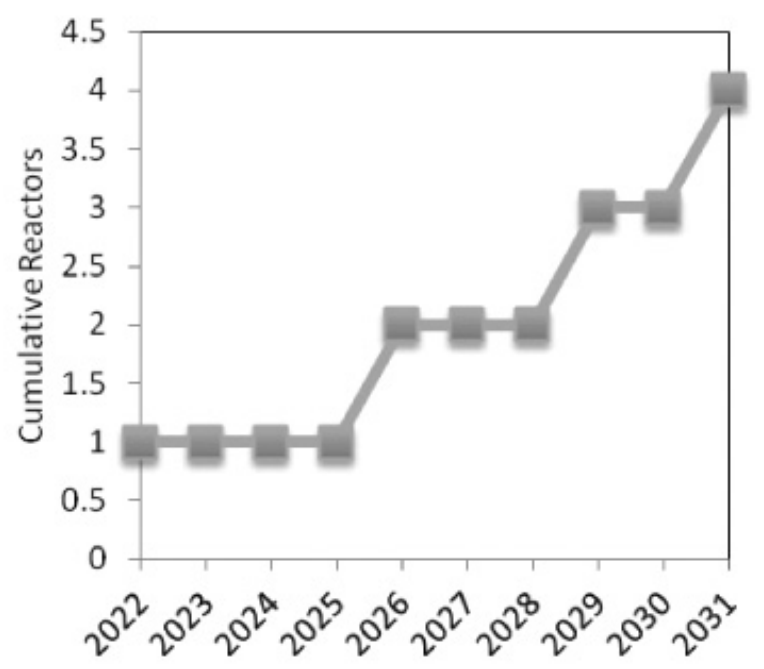

Fig. 6. Cumulative reactors to be installed in Kenya. 
Nuclear Materials (CPPNME) [4].

\section{NUCLEAR WASTE GENERATION}

Nuclear waste is generated through the use of nuclear energy for power generation through mining and milling of uranium, operation of NPPs, and decommissioning of nuclear facilities. Nuclear power generation is responsible for the production of various types of radioactive waste.

The low- and intermediate-level waste (LILW) in this study is generated as a result of reactor operation and decommissioning. For the sake of this work only LILW waste from operation of nuclear power plants is considered.

Generation of waste is subject to changes over time as a consequence of differences in economic and social situations. Waste volumes generated per unit energy over the years have been continuously reduced, due to technological advances and the increasing costs of unit waste disposal, and this has to be taken into account in estimating future waste production.

The most common types of low- and intermediatelevel waste (LILW) streams arising from the operation of nuclear power plants are spent filters, charcoal absorbers, spent resins, combustible dry active waste, non-combustible dry active waste, and borated liquid concentrate (evaporator concentrates, ion-exchange resin, slurries, sludge, filters, oils, solvents, and filter media).

Table 3-1. NPP operational waste arising/waste stream

\begin{tabular}{|c|c|c|c|}
\hline $\begin{array}{l}\text { Waste } \\
\text { Stream }\end{array}$ & $\begin{array}{l}\text { Waste type } \\
\text { arising }\end{array}$ & $\begin{array}{l}\text { Physical } \\
\text { form }\end{array}$ & Waste class \\
\hline Gaseous & $\begin{array}{l}\text { Filters, charcoal } \\
\text { absorbers }\end{array}$ & Dry solid & LILW-SL \\
\hline Liquid & $\begin{array}{l}\text { Oils, solvents, } \\
\text { evaporator } \\
\text { concentrates }\end{array}$ & liquid & LILW-SL \\
\hline Liquid & $\begin{array}{l}\text { Ion-exchange resin, } \\
\text { sludge, slurries, } \\
\text { filters, filter media }\end{array}$ & Wet solid & $\begin{array}{l}\text { LILW-SL to } \\
\text { LILW-LL }\end{array}$ \\
\hline Solid & Core components & Dry solid & $\begin{array}{l}\text { LILW-SL to } \\
\text { LILW-LL }\end{array}$ \\
\hline Solid & $\begin{array}{l}\text { Spent fuel racks, } \\
\text { combustible, } \\
\text { compactable, } \\
\text { noncombustible, } \\
\text { metals, wood, } \\
\text { concrete, rubble, } \\
\text { soil, absorbents }\end{array}$ & Dry solid & $\begin{array}{l}\text { LILW-SL to } \\
\text { LILW-LL }\end{array}$ \\
\hline
\end{tabular}

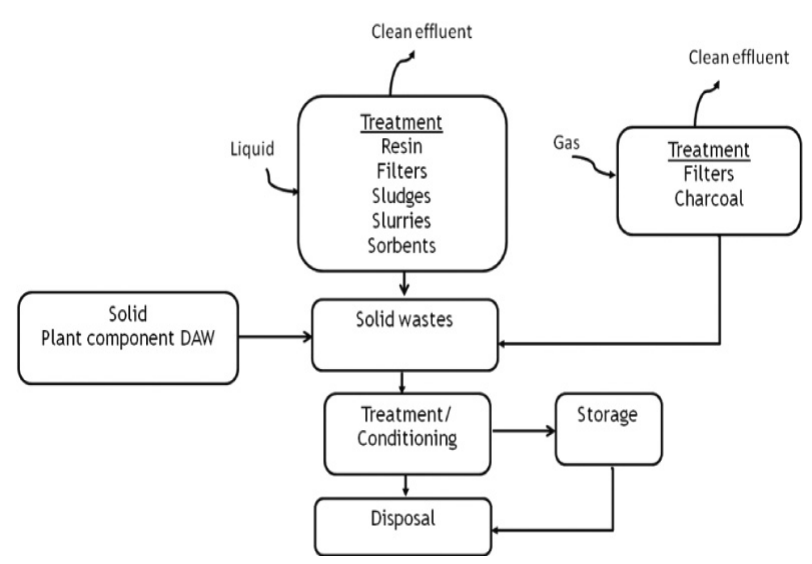

Fig. 7. NPP operational waste flow streams.

Fig. 7 illustrates the waste flow streams as they accelerate from generation through storage and disposal (cradle to grave).

When an average waste production for a particular reactor type is assumed, then multiplying it by the cumulative power generated by that reactor type allows a reasonable estimate to be made of the waste amounts generated. Adding up the waste generations of the various reactor types can then produce a national inventory of waste generated by reactor operations.

In this section, Korean inventories of radioactive waste generated by operation of nuclear power plants are estimated for the categories low- and intermediate-level waste (LILW) to enable the development of waste disposal facilities for newcomer countries.

How much waste can one expect from a nuclear power programme? In order to answer this question, it is necessary to assess the volume of radioactive waste generated from a specific nuclear power plant for a period of time. To do this, three case studies were considered.

Waste volume generated from Korean nuclear power sites were considered with greater emphasis placed on the Kori site followed by waste generated by the entire Korean nuclear power program from 2007 to 2012 and final waste generated from a specific nuclear power reactor, the APR 1400.

The number of drums of LILW expected from a nuclear power programme was computed by analyzing the radioactive waste inventory from a sample of Korean nuclear power reactors from three nuclear power plant sites (Hanul, Hanbit, Kori, and Wolsong) from four LILW waste streams.

Low- and intermediate-level waste (LILW) types such as dry active waste, spent filters, spent resins, and borated liquid concentrates are summarized in table 3-2 for three Korean sites.

Assuming an average number of drums per reactor, and then multiplying this value by the reactor's operat- 
C. L. Kim et al. : Deployment of Radioactive Waste Disposal Facility with the Introduction of Nuclear Power Plants (NPP) in Kenya

Table 3-2. Korean LILW waste streams up to 2000

\begin{tabular}{|c|c|c|c|c|c|c|c|}
\hline Site & Year & DAW & NDAW & SR & $\mathrm{SF}$ & BLC & Drum/unit \\
\hline \multirow{2}{*}{ KOR1 } & 1999 & 293 & 409 & 15 & 0 & 22 & 369 \\
\hline & 2000 & 337 & 467 & 60 & 0 & 60 & 439 \\
\hline \multirow{2}{*}{ KOR2 } & 1999 & 163 & 131 & 30 & 11 & 30 & 195 \\
\hline & 2000 & 187 & 93 & 25 & 5 & 25 & 169 \\
\hline \multirow{2}{*}{ WOL1 } & 1999 & 293 & 39 & 54 & 14 & 54 & 200 \\
\hline & 2000 & 159 & 19 & 25 & 8 & 25 & 106 \\
\hline \multirow{2}{*}{ WOL2 } & 1999 & 92 & 14 & 73 & 1 & 73 & 90 \\
\hline & 2000 & 83 & 9 & 66 & 1 & 66 & 80 \\
\hline \multirow{2}{*}{ HBT1 } & 1999 & 231 & 237 & 191 & 17 & 191 & 353 \\
\hline & 2000 & 194 & 88 & 119 & 0 & 119 & 133 \\
\hline \multirow{2}{*}{ HBT2 } & 1999 & 183 & 40 & 0 & 17 & 0 & 133 \\
\hline & 2000 & 141 & 19 & 25 & 0 & 25 & 122 \\
\hline \multirow{2}{*}{ HNL1 } & 1999 & 281 & 45 & 162 & 37 & 162 & 281 \\
\hline & 2000 & 254 & 50 & 109 & 39 & 109 & 259 \\
\hline \multirow{2}{*}{ HNL2 } & 1999 & 184 & 100 & 0 & 0 & 0 & 181 \\
\hline & 2000 & 228 & 67 & 0 & 0 & 0 & 191 \\
\hline \multicolumn{2}{|c|}{ TOTAL } & 3303 & 1827 & 954 & 150 & 961 & 3392 \\
\hline \multicolumn{7}{|c|}{ Average drums / reactor year } & 212 \\
\hline $\begin{array}{rl}* & \mathrm{KO} \\
\mathrm{WO} \\
\mathrm{HB} \\
\mathrm{HN}\end{array}$ & $\begin{array}{l}\text { I: Kori } \\
: \text { Wol } \\
\text { Hanb } \\
\text { : Hana }\end{array}$ & & & & & & \\
\hline
\end{tabular}

ing years, allows a reasonable estimate of the number of drums generated by the reactor's lifetime. Then summing up the waste generated by the number of reactors provides a national inventory of all waste drums generated by the whole national nuclear power program.

To estimate the total waste generated, it is assumed that the production number of drums is constant throughout the operation years and should apply to both past accumulations and future waste production.

The average number of drums generated before 2000 by the waste streams data from the four sites was found to be around 200 drums per reactor year. This value is not sufficient to project waste arising from a nuclear program today because it is produced from old data that dates back to the $19^{\text {th }}$ century. It cannot give a good estimate for the $21^{\text {st }}$ century due to technological advancements and improvements in operation and maintenance safety culture.

It was therefore necessary to use the most recent waste arising data from Kori NPPs from the years 2008 - 2012. The Kori nuclear power site has 4 nuclear power units (Kori units 1, 2, 3, and 4). Using the operating history of the four nuclear reactors, it was possible to assess the actual volume of waste generated from 2008 through 2012.

The actual waste arising from Kori nuclear power plants was assessed by using the GWe-years operating

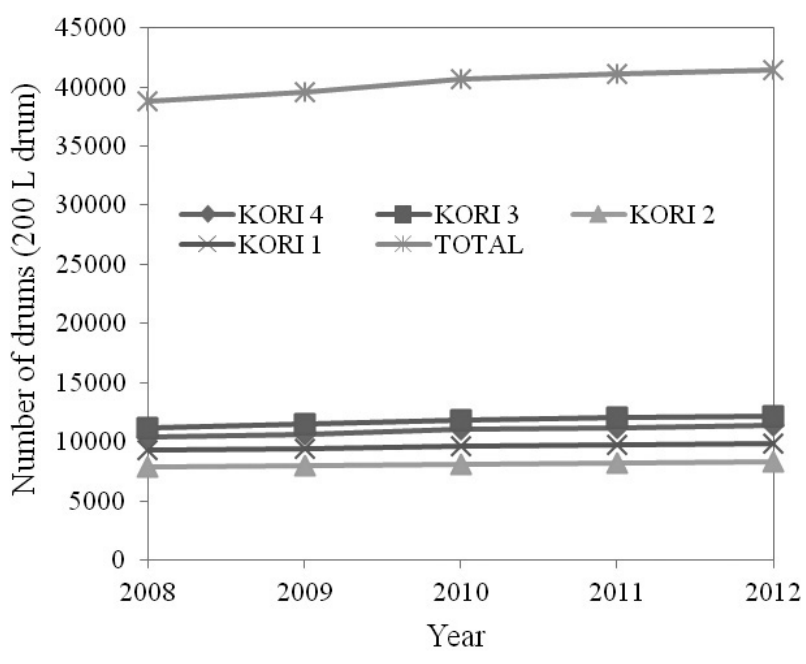

Fig. 8. Cumulative waste arising for Kori NPPs.

history, and the results are depicted in fig. 8 .

The average number of drums per reactor year was found to be $150 \mathrm{f} 200 \ell$ drums at the Kori nuclear power reactors. This value provides the most recent data for a good projection. But there is still need to consider a specific reactor type instead of using a generalized case.

Thus far we have been considering waste generation in a generalized case, which is not feasible. In order to obtain a good estimation of future projected waste generation, it is necessary to consider a specific reactor technology and reactor type, respectively.

Let's consider PWRs that are being used in Korea today. There are 19 PWRs in Korea as of June 2013 at four nuclear power sites. An analysis of LILW radioactive waste was done on PWRs reactors between 2007 and 2012 and the results are tabulated in table 3-3.

The average volume/GWe-yr for the PWRs was analyzed to be $56 \mathrm{~m}^{3}$. The volume has been gradually reducing from 2007 to 2012 due to technological advance-

Table 3-3. Inventory of LILW PWRs up to Dec 2012

\begin{tabular}{c|c|c|c|c}
\hline Year & $\begin{array}{c}\text { Number of } \\
\text { PWR } \\
\text { reactors }\end{array}$ & $\begin{array}{c}\text { Operating } \\
\text { history } \\
(\text { GWe-yrs })\end{array}$ & $\begin{array}{c}\text { Volume in } \\
\text { storage } \\
\left(\mathrm{m}^{3}\right)\end{array}$ & $\begin{array}{c}\text { Volume / } \\
\text { GWe-yr } \\
\left(\mathrm{m}^{3} / \mathrm{GWe}-\mathrm{yr}\right)\end{array}$ \\
\hline 2007 & 16 & 219.041 & $13,755.8$ & 62.8 \\
\hline 2008 & 16 & 232.043 & $13,945.8$ & 60.1 \\
\hline 2009 & 16 & 269.053 & $15,490.6$ & 57.6 \\
\hline 2010 & 16 & 285.781 & $15,708.2$ & 55.0 \\
\hline 2011 & 17 & 305.627 & $16,000.2$ & 52.4 \\
\hline
\end{tabular}




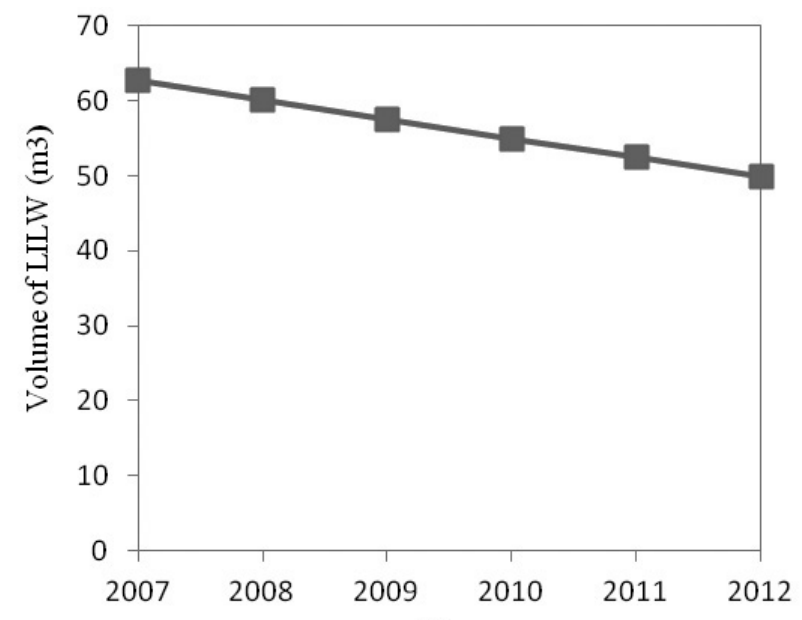

Fig. 9. Trend of waste arising from 2008-2012.

ments in volume reduction methodology, as depicted in fig. 9. This value is a generalized case from PWRs and therefore is not feasible to estimate waste arising for a nuclear programme.

\section{APR 1400 REFERENCE REACTOR}

The previous work only considered a generalized case of waste estimation from pressurized water technology.

Let's now consider a specific PWR reactor, the APR 1400 , to estimate actual waste generation.

The Advanced Power Reactor (APR1400) is a stan-

Table 4-1. APR 1400 operating details

\begin{tabular}{c|c}
\hline \multicolumn{2}{c}{ APR 1400 Operating details } \\
\hline Reactor type & PWR \\
\hline Model & APR 1400 \\
\hline Owner & KHNP \\
\hline Capacity & $1400 \mathrm{MWe}$ \\
\hline Thermal Capacity & $3983 \mathrm{MWt}$ \\
\hline Lifetime & $60 \mathrm{yrs}$ \\
\hline Construction start date & Oct. 2008 \\
\hline Commercial operation date & Sept.2013 \\
\hline Plant availability & $>90 \%$ \\
\hline Thermal margin & $>10 \%$ \\
\hline Construction period & $42 \mathrm{months}$ \\
\hline Exposure rate & $<1 \mathrm{man}-\mathrm{Sv} / \mathrm{yr}$ \\
\hline
\end{tabular}

dard evolutionary advanced light water reactor (ALWR) in the Republic of Korea that was developed in 2002. The reactor details are depicted in table 4-1.

It is the first reactor to apply the Korean new licensing process comprised of Standard Design Approval (SDA), Construction Permit (CP), and Operating License (OL).

\subsection{Radioactive Waste Management}

The radioactive waste consists of gaseous, liquid, and solid waste. The gaseous radioactive waste is mainly generated from degassing of the primary system and ventilation systems for the radiation controlled area in the APR 1400 reactor.

The liquid radioactive waste is mainly generated from the cleanup and maintenance processes of the reactor coolant and related systems containing radioactivity, whereas solid waste consists of dry active waste (DAW) and secondary process waste.

Dry active waste (DAW) is generated during maintenance and repair of contaminated systems and individual items such as used parts, papers, used clothes, gloves, shoes, and so on. Secondary waste is generated from the liquid and gaseous radioactive waste treatment system and includes concentrated wastes from evaporators, spent resin from demineralizers, and spent filters from liquid purification system of the reactor [5].

The waste also comprises primary and secondary coolant concentrations, concentrations of radioactive fission products, radioactive crud, $\mathrm{H}-3, \mathrm{C}-14$, radioactive effluents, leakage sources, and fission and corrosion products.

The Waste Management System consists of a Liquid Waste Management System (LWMS), Gaseous Waste Management System (GWMS), and Solid Waste Management System (SWMS), designed to protect the plant personnel, the public, and the environment from the impact of radioactive materials [5].

The reactor is designed to ensure that radioactive waste released to the environment is below the limits prescribed in both the Korean Regulatory Authority and USNRC regulations. The components and structures of the reactor are designed with appropriate safety margins so that radioactive releases do not occur.

\subsection{Estimated Waste Arising For APR 1400}

The yearly estimated waste of the APR 1400 has been developed by averaging past recent disposal data of the United States' actual operating nuclear reactors that apply similar waste processing systems. The estimated wastes include gaseous, liquid, and solid waste.

These estimated waste data have been used to project estimated waste arising for the Kenyan nuclear power programme. The estimated waste arising for both APR 1400 and Kenyan for two forms of radioactive waste are depicted in tables 4-2 and 4-3. 
C. L. Kim et al. : Deployment of Radioactive Waste Disposal Facility with the Introduction of Nuclear Power Plants (NPP) in Kenya

Table 4-2. Estimated liquid effluent for APR\&KNPP

\begin{tabular}{c|c|c}
\hline Waste Source & $\begin{array}{c}\text { APR 1400 flow rate } \\
\left(\mathrm{m}^{3} / \mathrm{day}\right)\end{array}$ & $\begin{array}{c}\text { KNPP flow rate } \\
\left(\mathrm{m}^{3} / \text { day }\right)\end{array}$ \\
\hline Shim bed & 600 & 429 \\
\hline Equipment drain & 250 & 178 \\
\hline Clean waste & 835 & 596 \\
\hline Dirty waste & 2594 & 1853 \\
\hline SG Blowdown & 51000 & 36857 \\
\hline Regenerate waste & 50000 & 35714 \\
\hline Total & 105,280 & 75,630
\end{tabular}

Table 4-3. Estimated waste arising from APR\&KNPP

\begin{tabular}{c|c|c}
\hline Waste Source & $\begin{array}{c}\text { APR } 1400 \\
\text { average Volume } \\
\left(\mathrm{m}^{3} / \mathrm{yr}-\mathrm{unit}\right)\end{array}$ & $\begin{array}{c}\text { KNPP average } \\
\text { volume } \\
\left(\mathrm{m}^{3} / \mathrm{yr}-\mathrm{unit}\right)\end{array}$ \\
\hline High activity resin & 8.4 & 6.0 \\
\hline Low activity resin & 14.8 & 10.6 \\
\hline Spent filters & 0.8 & 0.6 \\
\hline Dry active waste & 24.8 & 17.7 \\
\hline Total & 48.8 & 34.9 \\
\hline
\end{tabular}

The waste volume for a $1 \mathrm{GWe}$ power plant for the Kenyan program has been estimated to be $34.891 \mathrm{~m}^{3}$ (175 drums) per reactor year. This figure is good enough to be used to estimate waste arising from the Kenyan program because it represents the most recent data.

Utilizing the value of 175 drums per reactor year, Kenya is likely to generate 3,500 drums $\left(700 \mathrm{~m}^{3}\right)$ of LILW for the first 10 years of operation, 10,500 drums $\left(2,100 \mathrm{~m}^{3}\right)$ after 20 years of operation, and 35,000 drums of $200 \mathrm{l} /$ drum $\left(7,000 \mathrm{~m}^{3}\right)$ by the end of the program. The full generation trend is tabulated in table 4-4.

Table 4-4. Estimated waste arising for Kenyan program

\begin{tabular}{c|c|c|c|c}
\hline Time frame & Reactors & $\begin{array}{c}\text { Reactor } \\
\text { Years }\end{array}$ & $\begin{array}{c}\text { Volume of } \\
\text { LILW } \\
\text { (drums) }\end{array}$ & $\begin{array}{c}\text { Total } \\
\text { Volume } \\
\text { (drums) }\end{array}$ \\
\hline $2022-2025$ & 1 & 4 & 700 & 700 \\
\hline $2026-2028$ & 2 & 3 & 1,050 & 1,750 \\
\hline $2029-2030$ & 3 & 2 & 1,050 & 2,800 \\
\hline $2031-2072$ & 4 & 41 & 28,700 & 21,500 \\
\hline $2073-2076$ & 3 & 4 & 2,100 & 33,600 \\
\hline $2077-2079$ & 2 & 3 & 1,050 & 34,650 \\
\hline $2080-2081$ & 1 & 2 & 350 & 35,000 \\
\hline
\end{tabular}

※ APR: Advanced Pressurized Reactor 1400

KNPP: Kenya Nuclear Power Programme

USNRC: United States Nuclear Regulatory Commission

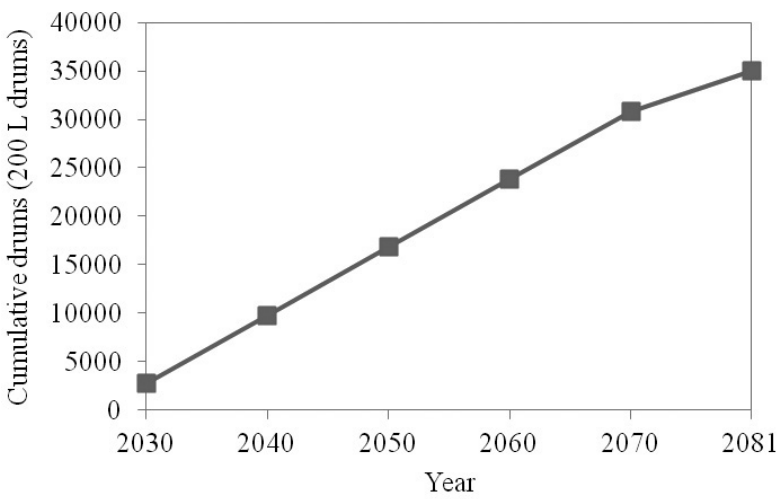

Fig. 10. Projected waste arising from NPPs for Kenya.

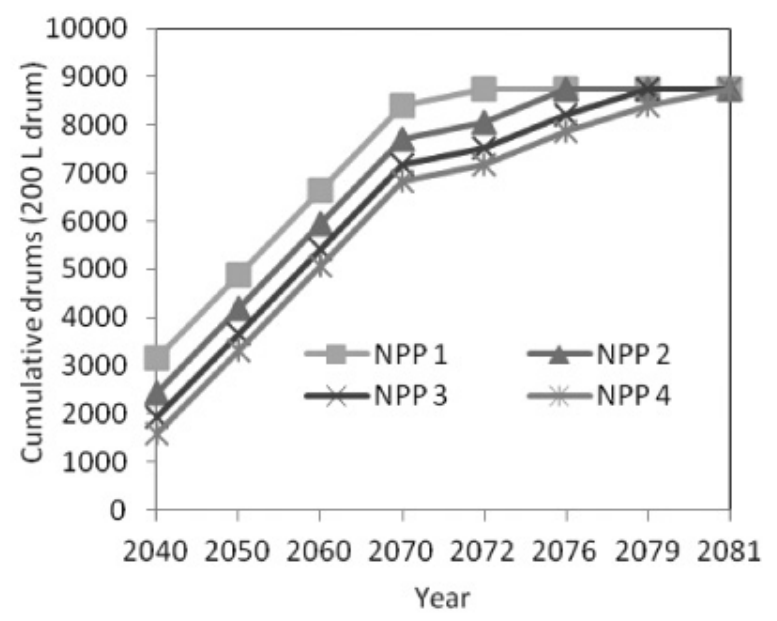

Fig. 11. Cumulative waste arising for units 1-4.

\section{DISPOSAL ALTERNATIVES OF SPENT FUEL}

The final destination of radioactive waste influences the waste management strategy to be followed.

The IAEA assists in international storage, which is not against international treaties and conventions. It is suitable for countries with small nuclear power or with no nuclear programs but with research reactors.

Spent fuel can be stored in cooling ponds at reactor sites to remove the heat generated during radioactive decay and allow the station to operate while disposal options are considered.

Extended storage provides radiation protection and allow the station to operate while methods for further waste minimization are pursued. This concept is also suitable for new entrants.

Wastes can be stored as packaged waste for an indefinite period of time in a retrievable condition where future generations would decide on the requirements for 
C. L. Kim et al. : Deployment of Radioactive Waste Disposal Facility with the Introduction of Nuclear Power Plants (NPP) in Kenya

Table 5-1. Merits and demerits of extended storage

\begin{tabular}{l|l}
\hline \multicolumn{1}{c|}{ Merits of } & \multicolumn{1}{c}{ Demerits of } \\
\hline $\begin{array}{l}\text { 1. Can retrieve waste packages easily } \\
\text { 2. Well controlled }\end{array}$ & $\begin{array}{l}\text { 1. Large repackaging } \\
\text { 3. Proven technology }\end{array}$ \\
$\begin{array}{l}\text { 2. Maintenance costs } \\
\text { 4. Relatively simple } \\
\text { 5. Allows economic waste processing }\end{array}$ & \multicolumn{1}{c}{ erations } \\
\hline
\end{tabular}

Table 5-2. Merits and demerits of direct disposal

\begin{tabular}{l|l}
\hline \multicolumn{1}{c|}{ Merits of direct disposal } & \multicolumn{1}{c}{ Demerits of direct disposal } \\
\hline & $\begin{array}{l}\text { 1. Early investment for disposal } \\
\text { 2. Small disposal volume per yr }\end{array}$ \\
$\begin{array}{l}\text { 1. Project efficiency } \\
\text { 2. Good public acceptance }\end{array}$ & $\begin{array}{l}\text { Radioactivity levels still high } \\
\text { during transport and disposal } \\
\text { 3. Minimum interim storage capac- } \\
\text { ity }\end{array}$ \\
$\begin{array}{ll}\text { 4. Repackaging not required } \\
\text { 4. Bad for countries without opera- } \\
\text { tion experience and adequate } \\
\text { manpower }\end{array}$ \\
\hline
\end{tabular}

Table 5-3. Merits and demerits of shared disposal

\begin{tabular}{|c|c|}
\hline Merits of shared storage facilities & Demerits of shared storage facilities \\
\hline $\begin{array}{l}\text { 1. Economy } \\
\text { 2. Access to safe disposal facili- } \\
\text { ties } \\
\text { 3. Enhanced global nuclear security } \\
\text { 4. Lower environmental impact } \\
\text { 5. Wider choice of geological } \\
\text { conditions }\end{array}$ & $\begin{array}{l}\text { 1. Transport } \\
\text { 2. Different legislations, defini- } \\
\text { tions } \\
\text { 3. Diversity of waste streams } \\
\text { 4. Cost distribution amongst partners } \\
\text { 5. Different time schedules } \\
\text { 6. Siting and politics }\end{array}$ \\
\hline
\end{tabular}

re-packing, rebuilding stores, and final deposition of the wastes.

Spent fuel can also be disposed of directly to a repository. This approach is suitable for states with many NPPs with operational experience, stable geological conditions, and adequate human resource [1].

Deferred disposal is also adopted because it facilities predisposal, allows economic waste processing, and decreases high level waste packages, and also due to national preference for surface storage.

Shared facilities allow states to share dedicated facilities and decrease waste disposal cost [1]. A centralized storage facility is more economical than an individual site because it requires a smaller workforce.

\section{LILW REPOSITORY PROGRAM}

The selection of appropriate radioactive waste disposal technology is dependent upon factors such as national policies, types and amounts of waste, and the rate at which waste is generated.

There are three proposals that a country may choose to

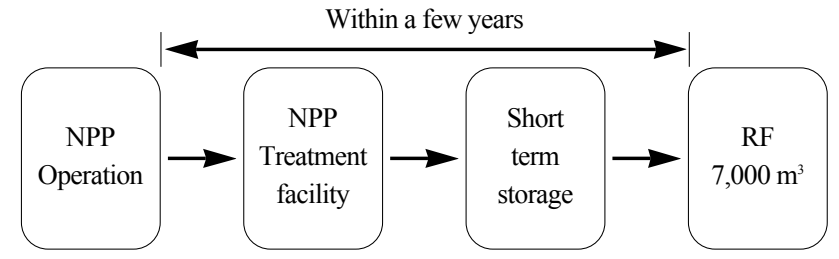

Fig. 12. Repository program within few years.

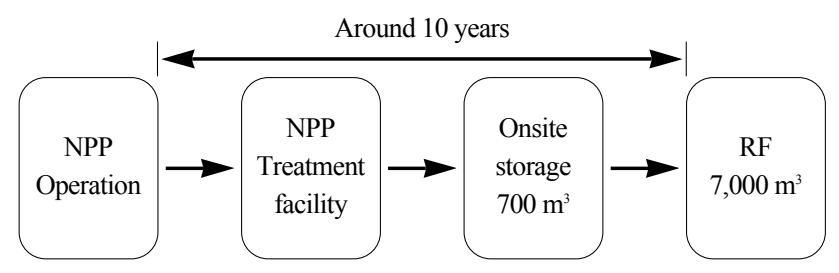

Fig. 13. Repository program around 10 years.

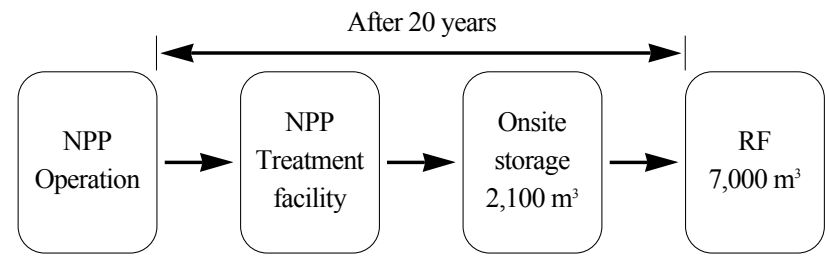

Fig. 14. Repository program after 20 years.

※ RF: Repository facility

Table 6-1. Merits \& demerits of repository 10 year later

\begin{tabular}{l|l}
\hline \multicolumn{1}{c|}{ Merits } & \multicolumn{1}{c}{ Demerits } \\
\hline $\begin{array}{l}\text { 1. Small storage capacity } \\
\text { 2. Siting for disposal facility may } \\
\text { be proceeded during NPP con- } \\
\text { struction }\end{array}$ & $\begin{array}{l}\text { 1. Relatively early investment for } \\
\text { disposal }\end{array}$ \\
$\begin{array}{l}\text { 3. Project continuity } \\
\text { (NPP + repository) }\end{array}$ & \\
\hline
\end{tabular}

Table 6-2. Merits \& demerits of repository in few years

\begin{tabular}{l|l}
\hline \multicolumn{1}{c|}{ Merits } & \multicolumn{1}{c}{ Demerits } \\
\hline & 1. Early disposal investment \\
& 2. Small disposal volume/yr \\
& 3. Possibility of no continuous \\
& flow of radioactive waste for \\
1. Project efficiency (nuclear pro- & states with one or two NPPs \\
gram + repository program can & 4. Suitable for states with many \\
be continued) & NPPs \\
2. Good public acceptance & 5. Radioactivity levels of wastes \\
3. Minimum interim storage & still high during transportation \\
capacity & \& disposal operation \\
& 6. Not desirable for countries \\
& without operation experience \\
& and adequate manpower \\
\hline
\end{tabular}


Table 6-3. Merits \& demerits of repository 20 year later

\begin{tabular}{c|c}
\hline \multicolumn{1}{c|}{ Merits } & \multicolumn{1}{c}{ Demerits } \\
\hline $\begin{array}{l}\text { 1. Economical disposal operation } \\
\text { (large disposal volume/year) }\end{array}$ & $\begin{array}{l}\text { 1. Requires a large on-site stor- } \\
\text { age capacity }\end{array}$ \\
$\begin{array}{l}\text { 2. Siting for repository will be } \\
\text { peferred investment for dis- } \\
\text { posal }\end{array}$ & $\begin{array}{l}\text { more difficult later } \\
\text { 3. Requires repackaging of waste } \\
\text { technology and new design } \\
\text { concepts }\end{array}$ \\
$\begin{array}{l}\text { drums } \\
\text { 4. Public acceptance regarding } \\
\text { disposal problem }\end{array}$ \\
\hline
\end{tabular}

carry out radioactive waste management: introducing repository within a few years; introducing repository around 10 years; and introducing repository after 20 years of commercial operation.

The advantages and drawbacks of the three proposals for radioactive waste management are highlighted below.

\section{SELECTION OF REPOSITORY DISPOSAL FACILITY}

This section provides some possible repository disposal facilities for low- and intermediate-level radioactive waste that are being practiced or that are being planned to be used in the future by different IAEA Member States.

The choice of a preferred disposal option is dependent upon safety level, national and international guidance, availability of resources, credit in prolonged institutional control, inventory of different waste categories, availability of sites, construction technology, public perception, and cost.

According to the IAEA, there are two major options for the disposal of LILW that are currently employed and planned by IAEA Member States: near surface facilities and geological repositories. Near-surface disposal is a proven and mature technology that finds application in many countries of the world. For the case of Kenya, only a near-surface disposal facility is discussed in this study.

Near-surface disposal facilities are currently in operation in many IAEA Member States such as the UK (Drigg), Spain (El Cabril), France (Center de l'Aube), Japan (Rokkasho-Mura), and USA (Barnwell, Richland, Clive). $62 \%$ of LILW repositories are engineered nearsurface facilities (vaults), 18\% are simplified near-surface facilities (trenches), and 7\% mined cavities (caverns) [6].

Trenches are a near-surface disposal option that is generally applied to LILW-SL and LILW-LL with very low activity. The trenches can be located above the groundwater level or within the saturated zone. This facility becomes cost effective when disposing of large volumes of wastes and large items of decommissioning waste.

Trenches near surface facilities are normally 20 - 30 feet deep and 100 feet wide. Materials such as sand, gravel, and stone are laid on the bottom of the trench to facilitate a free drainage system and to provide a dry foundation for the waste containers. The trenches have drain systems equipped with monitoring devices to detect water that has seeped into the trenches and any radionuclides that may have escaped from their containers into the water.

Disposal in trenches is suitable in areas with low rainfall and deep groundwater level such as arid areas and engineered barriers and designs are employed to minimize plant and animal intrusion. The concept provides long-term safety because of engineered barriers, natural site conditions, and suitable waste form. However, the post-closure control period must be sufficiently long to reduce the potential risk to acceptable levels. This concept finds applications in the USA and RSA.

Vaults incorporate multiple barriers and drainage systems to limit migration of radionuclides from the repository and to control water ingress. They are lined with reinforced concrete to provide a robust structure and improve isolation of waste. This concept can be employed both above and below ground level [7].

Vaults require backfilling, and a low permeable capping system is placed over the backfilled area to minimize water ingress and prevent intrusion by plants and

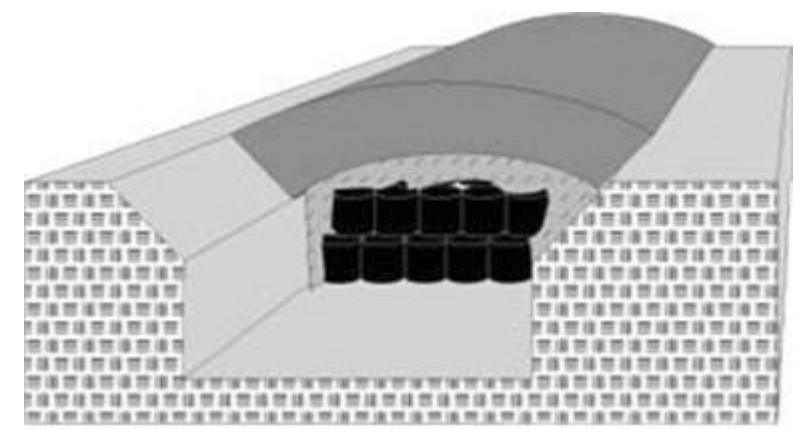

Fig. 15. Simplified trench disposal facility.

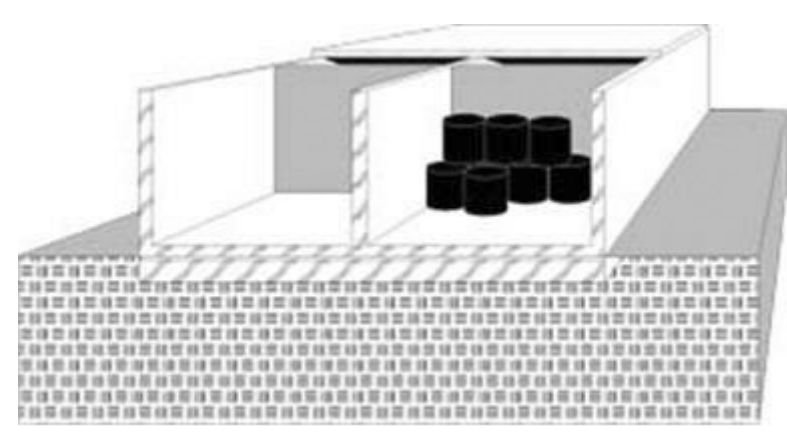

Fig. 16. Above ground vault disposal facility. 
animals. This concept is suitable for a broader spectrum of wastes and is utilized in France, the UK, Spain, Japan, and India [6].

Above ground vaults are built using reinforced concrete. The buildings are kept open both during and after placement of the waste. The facility is sealed with a clay cover. It requires monitoring for a considerable time to ensure that it poses no risk to health. It is easy to construct, but more exposed to humans.

Below ground Vaults are constructed using reinforced concrete, and the floors are sloped for water drainage. During operation the vaults are kept open, protected by a temporary roof, and are subjected to continual surveillance and maintenance after sealing to ensure that it poses no risk to health and the environment. Near-surface caverns are a form of excavated cavities where the distance below ground level is adequate to eliminate potential intrusion by plants, animals, and humans. The concept may incorporate a number of engineered safety barriers to eliminate migration of radionuclides from the repository.

Caverns cover a broader spectrum of radioactive wastes including higher proportions of long-lived wastes and are more secure against intrusion by plants, animals, and humans. However, they require more expensive barrier systems to prevent waste ingress.

Caverns below ground level have found applications in Sweden (SRF repository for short-lived radioactive waste at about $50 \mathrm{~m}$ ) and Finland (Olkiluoto \& Loviisa

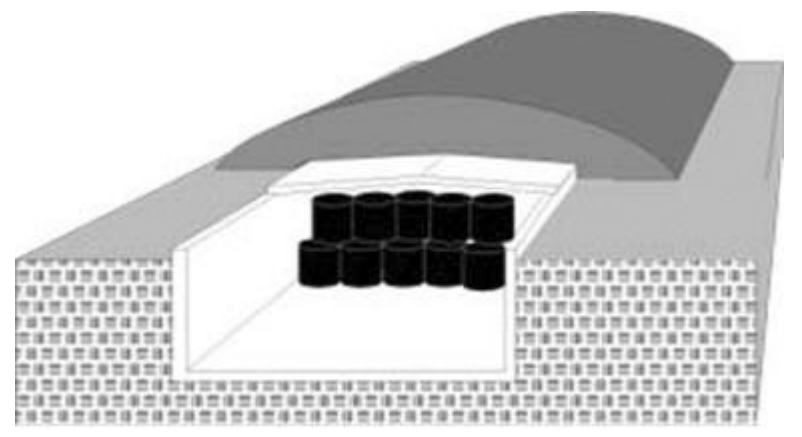

Fig. 17. Below ground vault disposal facility.

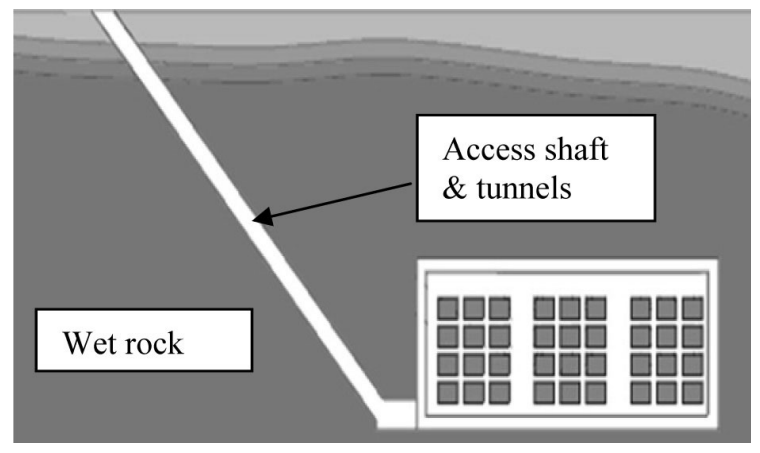

Fig. 18. Cavern disposal facility.
Table 7-1. Merits \& demerits of trench near-surface

\begin{tabular}{|c|c|}
\hline Merits of trenches & Demerits of trenches \\
\hline $\begin{array}{l}\text { 1. Guarantees long-term safety } \\
\text { 2. Inadvertent intrusion unlikely } \\
\text { 4. Construction is simple } \\
\text { 5. Construction is cheap }\end{array}$ & $\begin{array}{l}\text { 1. Requires long period of post } \\
\text { closure } \\
\text { 2. Inadequate distance from the } \\
\text { ground (tens of meters) }\end{array}$ \\
\hline
\end{tabular}

Table 7-2. Merits \& demerits of cavern near-surface

\begin{tabular}{l|l}
\hline \multicolumn{1}{c|}{ Merits of caverns } & \multicolumn{1}{c}{ Demerits of caverns } \\
\hline $\begin{array}{l}\text { 1. Adequate distance from } \\
\text { ground }(100 \mathrm{~m})\end{array}$ & \\
$\begin{array}{l}\text { 2. Inadvertent intrusion prohibited } \\
\text { 3. Covers a broad spectrum of } \\
\text { waste }\end{array}$ & $\begin{array}{l}\text { 1. More expensive to construct } \\
\text { 2. Complicated construction }\end{array}$ \\
$\begin{array}{l}\text { 4. Increased risk to workers dur- } \\
\text { ing construction }\end{array}$ \\
\hline
\end{tabular}

Table 7-3. Merits \& demerits of vaults near-surface

\begin{tabular}{l|l}
\hline \multicolumn{1}{c|}{ Merits of vaults } & \multicolumn{1}{c}{ Demerits of vaults } \\
\hline $\begin{array}{l}\text { 1. No migration of waste from } \\
\text { facility }\end{array}$ & $\begin{array}{l}\text { 1. More expensive than trench } \\
\text { 2. System requires backfilling }\end{array}$ \\
$\begin{array}{l}\text { 2. Inadvertent intrusion prohibited } \\
\text { 4. Robust structural integrity } \\
\text { 5. Covers a broad spectrum of } \\
\text { waste }\end{array}$ & $\begin{array}{l}\text { 4ystem } \\
\text { 4. Construction is complicated } \\
\text { 5. Above surface facility is more } \\
\text { exposed in terms of visual } \\
\text { table and easy to construct } \\
\text { impact }\end{array}$ \\
$\begin{array}{l}\text { 7. Below surface is built in solid } \\
\text { geology and therefore not } \\
\text { exposed to elements }\end{array}$ & $\begin{array}{l}\text { 6. Below surface is constructed in } \\
\text { water table }\end{array}$ \\
\hline
\end{tabular}

power stations at about $100 \mathrm{~m}$ ), Czech Republic, France, Japan, Netherlands, Spain, UK, USA, Sweden, Finland, and Norway.

Based on the analysis of the three types of near-surface disposal facilities, merits and demerits of each facility are presented herein.

\section{DISCUSSION}

The present study has established a radioactive waste disposal facility for Kenya by considering already existing waste arising available in Korea. The analysis of radioactive waste facility considered introducing the repository program around 10 years after introducing nuclear program.

The best way is to store LILW temporarily within NPPs sites pending construction of final disposal facility. Introducing repository program within a few years of nuclear programs depends on the availability of funds, and during that time the radioactivity levels of wastes 
are still high and may impart high radiation doses to workers during transport.

When the storage period becomes very long, there must be a financial commitment in regard to radioactive waste management cost. Long term on-site storage is not a good option because it requires repackaging of waste drums before sending to repository.

Introducing repository program within around 10 years of commercial operation of nuclear power program has many merits as compared to introducing repository program far much later or having repository program running within a few years.

The provision of long term trench disposal coupled with cost effectiveness makes it suitable for deployment. The large tracks of desert land in the northern part of Kenya ensure that the water table is much below underground thus making trench near-surface disposal facility conducive. Trench facility is also cheap and simple to construct, and has a good drainage system as compared to vault and cavern. Therefore, trench near surface disposal facility is the best choice for Kenya.

\section{CONCLUSION}

The proposed Kenyan nuclear power programme will generate operational wastes during plant maintenance such as spent resins, spent filters, combustible and noncombustible dry active waste (DAW) and borated liquid waste concentrate.

Estimated radioactive waste arising from the operational phase of APR 1400 together with actual waste arising from Kori site has been assessed and projected waste arising expected from the Kenyan nuclear power programme established.

The best strategy is to store the LILW and spent fuel temporarily within reactor sites pending construction of a final disposal facility. The repository facility should be introduced around 10 years of reactor operation. Research \& development on volume reduction technology and conceptual design of disposal facility of LILW should be pursued.

The implementation of improved waste treatment procedures and equipment at nuclear power plants can enable the operator to reduce annual waste generation from 175 drums per reactor year to a much lesser value.

\section{REFERENCES}

[1] IAEA, The Principles of Radioactive Waste Management, Safety Series No.111-F, Vienna,
Austria (1996)

[2] IAEA, Classification of Radioactive Waste, Safety Standards Series GSG-1, Vienna, Austria (2009)

[3] IAEA, Technical Meeting on corporation for human resource development among embarking and experienced countries. Experiences and lessons learned in addressing the challenges of training in Kenya, Vienna, Austria (2013)

[4] Nuclear Energy for industrialization, A case study of Kenya's vision 2030, presented to the Dialogue Forum on "Long Term Prospects for Nuclear Energy.", (2012)

[5] Standard Safety Analysis Report APR 1400, Korea Hydro and Nuclear Power (KHNP) (2002)

[6] K.W. Han, et al. IAEA Bulletin 39(1), Radioactive Waste Disposal Global Experience and Challenge (1997)

[7] E. L. Gershey, et al., Low-Level Radioactive Waste from Cradle to Grave, Van Nostrand Reinhold, New York (1990) 